Revista Brasil. Bot., V.33, n.3, p.407-414, jul.-set. 2010

\title{
In vitro culture at low temperature and ex vitro acclimatization of Vriesea inflata an ornamental bromeliad
}

\author{
ANDREA NUNES VAZ PEDROSOํㅗㅇ, ROSMARI APARECIDA DE MORAIS LAZARINI', \\ VÍVIAN TAMAKI ${ }^{1}$ and CATARINA CARVALHO NIEVOLA ${ }^{1,2}$
}

(received: May 04, 2008; accepted: May 20, 2010)

\begin{abstract}
In vitro culture at low temperature and ex vitro acclimatization of Vriesea inflata an ornamental bromeliad). In vitro culture by seeds is a technique for preservation of threatened species because it may provide a large number of plants with genetic diversity. The bromeliad Vriesea inflata (Wawra) Wawra, an ornamental bromeliad, is extensively and illegally collected from the nature and must be preserved. It is possible to form plant threatened collections in vitro by reducing the temperature of culture, while occupying little space, with the consequent reduction of maintenance costs. This work evaluated the influence of temperature on in vitro growth and morphology of plants of $V$. inflata, with the aim of establishing a slow growth-rate and analyzing the ex vitro acclimatization. Seeds were germinated in vitro in Murashige and Skoog (MS) medium, with macronutrients reduced to $50 \%(\mathrm{MS} / 2)$. After three months the plants were transferred to flasks of new same medium and kept in two germination chambers with the temperature adjusted to $15^{\circ} \mathrm{C}$ and to $28^{\circ} \mathrm{C}$. After 24 months the plants were subject to biometric, photosynthetic pigments content and anatomical analyses. Results showed that plants maintained at $15^{\circ} \mathrm{C}$ were smaller than those at $28{ }^{\circ} \mathrm{C}$. Nevertheless, there were no alterations in pigments content, anatomy. In both treatments there was a survival rate of $100 \%$. This work showed that plants of this species can be kept in vitro at $15{ }^{\circ} \mathrm{C}$ with the aim of forming a slow-growth collection, thereby seeking its preservation, and can be transferred to growth at ex vitro condition to achieved $100 \%$ survival rate.
\end{abstract}

Key words - anatomy, Bromeliaceae, conservation, growth, photosynthetic pigments

RESUMO - (Cultivo in vitro em temperatura baixa e aclimatização ex vitro de Vriesea inflata, uma bromélia ornamental). O cutivo in vitro iniciado a partir de sementes pode ser utilizado para preservação de espécies ameaçadas porque contribui para o fornecimento de um grande número de plantas com diversidade genética. Vriesea inflata (Wawra) Wawra, uma bromélia ornamental, é extensivamente e ilegalmente coletada da natureza, sendo importante sua preservação. Por meio do cultivo in vitro é possível formar coleções de plantas ameaçadas, sob crescimento lento, ocupando pouco espaço, com redução dos custos de manutenção das culturas. Este trabalho avaliou a influência da temperatura sobre o crescimento e morfologia de plantas de V. inflata mantidas in vitro, com objetivo de diminuir o crescimento, além de verificar a aclimatização destas para a condição ex vitro. Sementes de $V$. inflata foram germinadas utilizando-se o meio de Murashige and Skoog (MS) com macronutrientes reduzidos à metade $(\mathrm{MS} / 2)$. Após três meses as plantas foram transferidas para frascos contendo o mesmo meio e mantidos em câmaras de germinação, com temperaturas ajustadas para $15^{\circ} \mathrm{C}$ e $28^{\circ} \mathrm{C}$. Após 24 meses essas plantas foram submetidas à analises biométricas, anatômicas e de pigmentos fotossintéticos. Verificou-se que as plantas mantidas a $15{ }^{\circ} \mathrm{C}$ foram menores que aquelas cultivadas a $28^{\circ} \mathrm{C}$. A taxa de sobrevivência foi de $100 \%$ e não houve alterações no conteúdo de pigmentos e na anatomia. Este trabalho mostrou que plantas dessa espécie podem ser mantida in vitro a $15^{\circ} \mathrm{C} \mathrm{com} \mathrm{o} \mathrm{objetivo} \mathrm{de} \mathrm{se} \mathrm{estabelecer}$ uma coleção de crescimento lento visando à preservação, além de mostrar que essas plantas apresentaram uma taxa de $100 \%$ de sobrevivência quando transferidas para condições ex vitro.

Palavras-chave - anatomia, Bromeliaceae, conservação, crescimento, pigmentos fotossintéticos

\section{Introduction}

The Bromeliaceae form a group of 57 genera and around 3,086 species (Luther 2006). In various ecosystems, many bromeliads have been reduced in number or even eradicated due to habitat destruction as a result of anthropic action, such as increasing deforesting, and the occurrence of selective extraction (Rocha et al.

\footnotetext{
1. Instituto de Botânica, Núcleo de Pesqusa em Plantas Ornamentais, Avenida Miguel Estéfano, 3687, 04301-902 São Paulo, SP, Brazil. Corresponding author: ccnievola@uol.com.br
}

2004). The atributes of colorful bracts and flowers that can last for several months, and of leaves of high visual appeal, confer elements of a very highly appreciated esthetic value, much appreciated on the ornamental plant market, as occurs with the epiphyte species native of the Atlantic Rain Forest, Vriesea inflata (Wawra) Wawra. This bromeliad is widely commercialized in plant-sales outlets or even offered for commerce on the road-side by informal sales-personnel (Nunes 2002). Generally, and in order to supply plant markets, and with the additional possibility of quick and easy profit, the situation generates the appearance of specialized collectors operating on 
a commercial scale (Duran \& Monteiro 2005). Thus, the development of conservation measures becomes necessary in order to avoid the extinction of the target species through illegal extraction.

In vitro culture of bromeliads could be a strategy for preservation and production of seedlings of phytosanitary quality on a large scale for ornamental plant commercialization and to be used for reintroduction programs of impacted areas (Silva et al. 2007, Bellintani et al. 2007, Rech-Filho et al. 2009, Silveira et. al 2009). Commercial in vitro culture techniques are mainly used for the production of selected genotypes, thus permitting the production of thousands of identical plants, over a short period of time, starting from just one explant (Hartmann et al. 2002). This type of culture can also be used for the conservation of germplasm with commercial and ecological interests (Sarasan et al. 2006). The micropropagation in the world's largest botanical garden - the Royal Botanic Gardens, Kew, in England possesses an extensive in vitro collection which includes many plant species drawn from all over the world and considered under threat of extinction, whereby the dissemination of in vitro protocols becomes necessary in order to promote the continuous development and application of conservation techniques (Sarasan et al. 2006). The establishment of in vitro culture starting from seeds contributes to maintaining the genetic variability of a certain species, a necessary procedure in conservation programmes (Mercier \& Nievola 2003).

The conservation of germplasm of plant species over a long span of time can be done through reducing growth without affecting the development, by the use of constant low temperatures (Jouve et al. 2000, Islam et al. 2005, Amoo et al. 2009). Nevertheless, it must consider that the adaptation of plants to variations of temperature in natural environments occurs seasonally. However, tropical plants do not subsist at low temperatures throughout all the life cycle, whereby an investigation of the adaptive capacity of these plants to a constant low temperature becomes important. Thus, for this type of in vitro preservation, it is necessary to analyze the survival rate, in vitro and after acclimatization. Gonçalves \& Romano (2007) evaluated the survival and morphology of plants of Drosophyllum lusitanicum (L.) Link, a threatened species, and the results presented show that cultures can be conserved in vitro for eight months at $5{ }^{\circ} \mathrm{C}$. Pretreatment of plants at low temperature $\left(15 \pm 2{ }^{\circ} \mathrm{C}\right)$ for 10 days before transfer to greenhouse conditions increased the survival percentage (Malik et al. 2009). Jouve et al. (2000) showed that poplar can be conserved in vitro more than one year at $10{ }^{\circ} \mathrm{C}$, and
Bekheet et al. (2002) showed that Phoenix dactylifera L. plants were successfully stored for 12 months at $5{ }^{\circ} \mathrm{C}$. However, there are no reports about slow growth bromeliad preservation at low temperature.

Variations in anatomy, morphology and physiology can reflect the plants adaptability to the differences in the temperature changes (Klich 2000). Low temperatures also affect the size and shape of photosynthetic cells, amount of pigments, and consequently photosynthesis itself (Georgieva \& Lichtenthaler 2006). The chlorophyll and other pigments can be influenced by temperature changes (Carter \& Knapp 2001) and can indicate nitrogen utilization by plants (Bigot \& Bocaud 1996, von Wiren et al. 1997).

There are few reports regarding studies on the influence of temperature in bromeliads cultivated in vitro. Nievola et al. (2005) observed that plants of the bromeliad Ananas comosus L. Merril obtained from an in vitro clone already presented a decrease in growth, as well as alterations in anatomy and pigments content when cultured for three months under a thermoperiod of $28{ }^{\circ} \mathrm{C}$ light $/ 15^{\circ} \mathrm{C}$ dark, compared to those kept at a constant temperature of $28^{\circ} \mathrm{C}$. According to Pierik (1987), the use of a temperature of $15^{\circ} \mathrm{C}$ for tropical plants is adequate to produce a decrease in growth without causing plants damage.

The aim of the present work was to evaluate the influence of temperature on in vitro growth and morphology of the ornamental bromeliad $V$. inflata, aiming to establish a slow growth rate, and analyze the ex vitro acclimatization.

\section{Material and methods}

Seeds of Vriesea inflata (Wawra) Wawra were harvested from several plants (figure 1) from the Estação Biológica do Alto da Serra de Paranapiacaba-SP-Brazil (2346’35.8” S and $46^{\circ} 18^{\prime} 42.9^{\prime \prime} \mathrm{W}$ ) and from specimens from different parts of Atlantic Forest present in the Bromeliaceae collection of the Instituto de Botânica, SP (Brazil).

Establishing in vitro culture - Seeds were sterilized for five minutes in ethanol (70\%) and then were immersed in a solution of sodium hypochlorite $2 \%$ with drops of Tween 20 for one hour, followed by five rinses in sterilized water. Seeds were then inoculated in Petri dishes containing Murashige \& Skoog (1962) medium (MS) with macronutrients reduced to $50 \%(\mathrm{MS} / 2)$, supplemented with $2 \%$ sucrose, $0.1 \mathrm{mg} \mathrm{L}^{-1}$ of thiamine-HCL, $100 \mathrm{mg} \mathrm{L}^{-1}$ of myo-inositol and $7 \mathrm{~g}$. L $\mathrm{L}^{-1}$ of agar (Bacto Difco) with $\mathrm{pH}$ adjusted to 5.8. Cultures were maintained in a growth room at $26 \pm 2{ }^{\circ} \mathrm{C}$ and $55 \mu \mathrm{mol} \mathrm{m} \mathrm{s}^{-2} \mathrm{~s}^{-1}$ light photons provided by cool white lamps during 12 hours of light regime for three months (figure 2). 
Experimental design of in vitro culture at different temperatures - Eighty three months old plants were distributed among eight flasks of $250 \mathrm{~mL}$, with 10 plants in each one, with the same nutrient medium ( $40 \mathrm{~mL}$ of MS/2 medium) described above. Plant material was kept in two growth-chambers adjusted to $15^{\circ} \mathrm{C}$ and $28{ }^{\circ} \mathrm{C}$ (figures $3 \mathrm{~A}$ and 3B). After 24 months, 20 plants, from each temperature culture condition, were assigned to biometric analyses (length of the longest root, numbers of roots and leaves and length of the shoots), besides anatomy and amounts of fresh and dry masses of both roots and shoots, as well as the quantity of photosynthetic pigments in both group of plants. The experiment was carried out in a completely randomized design. The other 40 plants cultivated in vitro at $15^{\circ} \mathrm{C}$ were used for acclimatization (figures 4 and 5).

Photosynthetic pigment content - Shoots were cut into small pieces and spread on a Petri dish containing humid
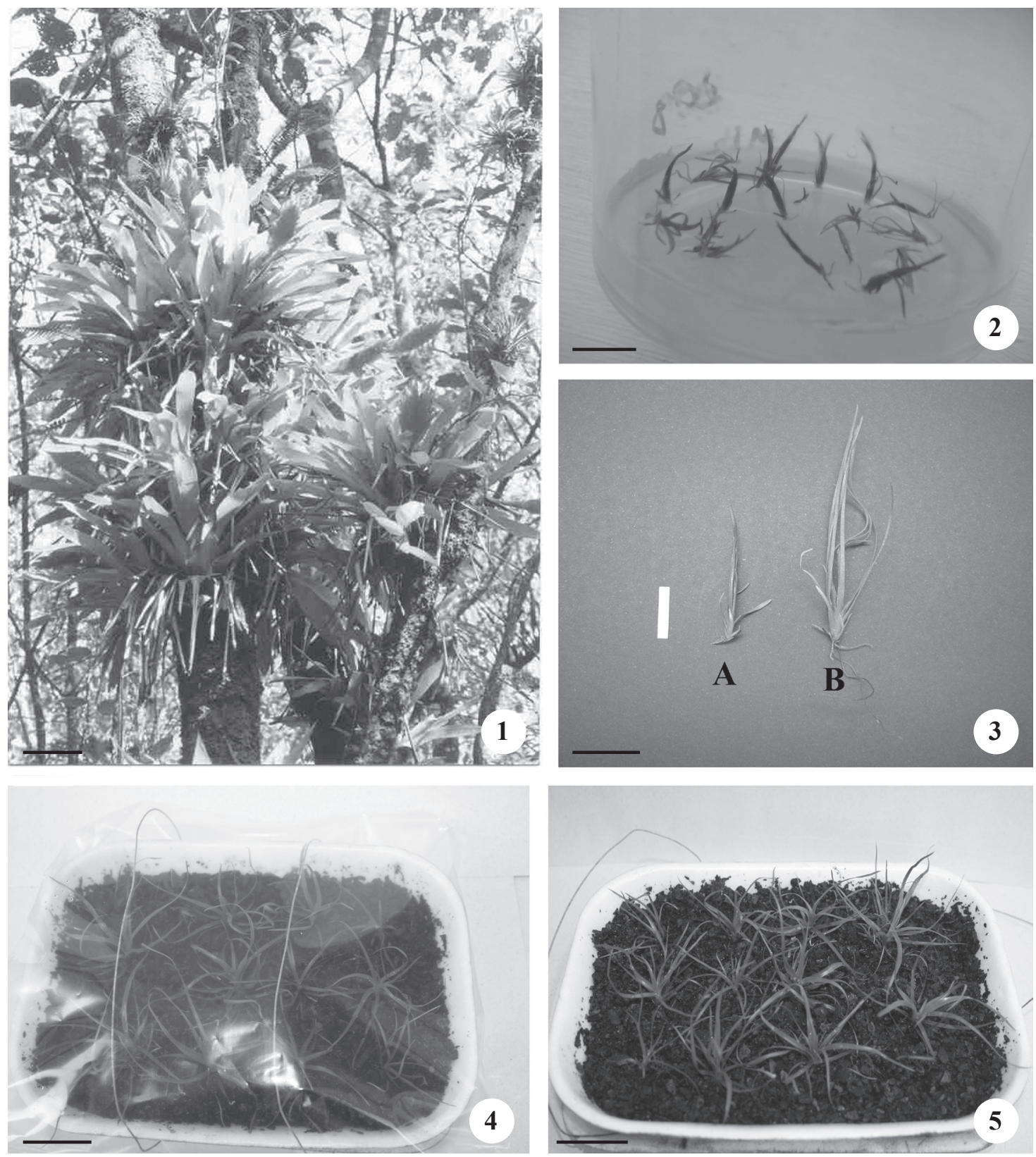

Figures 1-5. 1. Adult plants of Vriesea inflata at Estação Biológica do Alto da Serra de Paranapiacaba-SP-Brazil. 2. In vitro plantlets from seeds cultured in MS medium with macronutrients reduced to $50 \%$ for three months at $28{ }^{\circ} \mathrm{C}$. 3 . Growth of shoot at $15^{\circ} \mathrm{C}(3 \mathrm{~A})$ and at $28^{\circ} \mathrm{C}(3 \mathrm{~B})$ after two years. 4. First step of acclimatization of plants cultured at $15^{\circ} \mathrm{C}$ (enclosing plants placed in tray in a plastic sack) for two months. 5. Plant growth in greenhouse for one month after the first step. Bar $=14 \mathrm{~cm}$ (5); $0.8 \mathrm{~cm} \mathrm{(6);} 1 \mathrm{~cm} \mathrm{(7);} 3.5 \mathrm{~cm}(8,9)$. 
filter paper. Three replicates of $0.5 \mathrm{~g}$ of fresh mass of shoot were harvested for determination of photosynthetic pigments. Fresh leaf tissue $(0.5 \mathrm{~g})$ was homogenized with $5 \mathrm{~mL}$ of cold pure acetone. The homogenate was filtered (Whatman paper, number 1) and its solid residue was washed up to a final volume of $25 \mathrm{~mL}$. Chlorophyll concentration of the filtrate was measured spectrophotometrically and calculated according to Lichtenthaler (1987): chlorophyll $\mathrm{a}+\mathrm{b}=7.05 \times$ $\mathrm{A}_{661.6}+18.09 \times \mathrm{A}_{644.8} ;$ carotenoid $=\left[1000 \times \mathrm{A}_{470}-1.90 \times\right.$ $\left(11.24 \times \mathrm{A}_{661.6}-2.04 \times \mathrm{A}_{644.8}\right)-63.14 \times\left(20.13 \times \mathrm{A}_{644.8}-4.19 \times\right.$ $\left.\left.\mathrm{A}_{661,6}\right)\right] / 214$

Anatomical analysis - The samples from both treatments were fixed in FAA (formalin: acetic acid: ethanol $70 \%-$ 1:1:18) (Johansen 1940). Fragments from the midrib of the most developed leaf were diafanized according to Strittmatter (1973), and were embebed in polyethylene glycol 2,000. The cross-sections of each fragment with $12 \mu \mathrm{m}$ were stained with astra blue $1 \%$ and safranin $1 \%(9: 1)$ and permanently mounted on microscopic slides with cover slips using Permount ${ }^{\mathbb{}}$. Measurements were obtained using a microscope equipped with a camera for image capturing and a semi-automatic measuring system (Olympus Model: BX41-BF-III) along with image analyses software: Image-Pro Express 4.0.1 Media Cybernetics.

Experimental design of acclimatization - The 40 plants maintained in vitro at $15^{\circ} \mathrm{C}$ for two years were transferred to in vitro conditions at $28^{\circ} \mathrm{C}$ distributed in four flasks of $250 \mathrm{~mL}$ (with $40 \mathrm{~mL}$ of MS/2 medium). After one year in vitro at $28^{\circ} \mathrm{C}, 20$ plants were transferred to acclimatization. The first step of acclimatization consisted of enclosing plants for two months in trays, with substrate (fine commercial Pinus bark esterilized) and in a plastic sack, before transfer to grow in greenhouse (figure 4). After one month the survival and the number and length of leaves were determined (figure 5). The results were compared to the other 20 plants maintained in vitro condition. The experiment was carried out in a completely randomized design.

Data analysis - The means were compared using the $t$-test.

\section{Results and discussion}

Table 1 shows the slow growth of $V$. inflata cultured at $15^{\circ} \mathrm{C}$, without alterations in the tissues and in the pigments as those grown at $28^{\circ} \mathrm{C}$. A survival rate of $100 \%$ of plants cultured in both treatments was observed during the two years of culture. Plants kept at $15^{\circ} \mathrm{C}$ presented significantly smaller length and less dry mass of both, roots and shoots, in relation to those kept at $28^{\circ} \mathrm{C}$, thus demonstrating the influence of low temperature on growth. Similar results were observed by Pérez et al. (2001) with Festuca arundinaceae Schreb. Cv. Tima, in which the drop in temperature from $25^{\circ} \mathrm{C}$ to $12{ }^{\circ} \mathrm{C}$ caused a reduction in growth and in the leaf area of plants.

A reduction in growth, as a result of the influence of temperature in the bromeliad Ananas comosus (L.) Merr., was reported by Nievola et al. (2005). These authors showed that the external and internal morphology of the plants had been altered depending on the temperature of culture. The leaves of plants kept at $15^{\circ} \mathrm{C}$ during the dark period were thicker (had more dry mass) although

Table 1. Growth parameters, photosynthetic pigments and survival of Vriesea inflata cultured at $15{ }^{\circ} \mathrm{C}(n=20)$ and $28{ }^{\circ} \mathrm{C}$ $(n=20)$ after two years. Means with the same letter within the same line are not significantly different at the $5 \%$ level.

\begin{tabular}{|c|c|c|c|}
\hline & & $15^{\circ} \mathrm{C}$ & $28^{\circ} \mathrm{C}$ \\
\hline & & \multicolumn{2}{|c|}{$\bar{x} \pm s$} \\
\hline \multirow[t]{4}{*}{ Root } & Quantity of roots $\left(\mathrm{n}^{\mathrm{o}}\right) /$ plant & $4.33 \pm 0.81 \mathrm{a}$ & $3.12 \pm 0.64 \mathrm{a}$ \\
\hline & Lenght $(\mathrm{cm})$ & $0.87 \pm 0.33 b$ & $2.80 \pm 0.56 \mathrm{a}$ \\
\hline & Fresh mass $(\mathrm{mg}) /$ plant & $1.2 \pm 0.1 \mathrm{~b}$ & $5.00 \pm 0.01 \mathrm{a}$ \\
\hline & Dry mass (mg)/plant & $0.28 \pm 0.03 b$ & $1.5 \pm 0.1 \mathrm{a}$ \\
\hline \multirow[t]{8}{*}{ Shoot } & Quantity of leaves $\left(\mathrm{n}^{\circ}\right) /$ plant & $8.77 \pm 0.66 \mathrm{a}$ & $9.50 \pm 0.90 \mathrm{a}$ \\
\hline & Lenght $(\mathrm{cm})$ & $2.04 \pm 0.19 b$ & $3.66 \pm 0.43 \mathrm{a}$ \\
\hline & Fresh mass $(\mathrm{mg}) /$ plant & $16.7 \pm 1.3 \mathrm{~b}$ & $41.9 \pm 4.9 \mathrm{a}$ \\
\hline & Dry mass $(\mathrm{mg}) /$ plant & $2.8 \pm 0.4 \mathrm{~b}$ & $4.3 \pm 0.8 \mathrm{a}$ \\
\hline & Chlorophyll $\mathrm{a}+\mathrm{b}\left(\mu \mathrm{g}\right.$ of pigment $\left.\mathrm{g} \mathrm{FM}^{-1}\right)$ & $848.64 \pm 109.18 \mathrm{a}$ & $727.25 \pm 224.32 \mathrm{a}$ \\
\hline & Carotenoids ( $\mu \mathrm{g}$ of pigment $\mathrm{g} \mathrm{FM}^{-1}$ ) & $213.47 \pm 18.45 \mathrm{a}$ & $218.77 \pm 43.34 \mathrm{a}$ \\
\hline & Quantity of cells of aquiferous parenchyma ( $\left.n^{\circ}\right)$ & $68.3 \pm 1.4 \mathrm{~b}$ & $102.0 \pm 2.0 \mathrm{a}$ \\
\hline & & \multicolumn{2}{|c|}{$\%$} \\
\hline \multicolumn{2}{|c|}{ Survival rate } & $100 \%$ & $100 \%$ \\
\hline
\end{tabular}


they were smaller in comparison to those cultured at $28{ }^{\circ} \mathrm{C}$. The result of greater dry mass was associated to an increase in the number of cell layers in plants cultured under lower temperatures during the dark period.

For the species $V$. inflata studied herein, plants cultured at different temperatures presented the same structures and possessed the same tissues. Plants from both treatments presented elongated cells, rectangular and sinuous cell wall in both abaxial and adaxial surfaces (figures 6 and 8). In cross-section, cells presented uniseriate epidermis on the abaxial and adaxial surfaces (figures 7 and 9). Below the adaxial surface cells, there were three layers of aquiferous parenchyma, followed by a spongy parenchyma with two more layers of aquiferous parenchyma (figures 7 and 9). The number of cells correlates to larger values of dry mass. The highest value of dry mass was observed for plants kept at $28^{\circ} \mathrm{C}$, which has 102 cells of aquiferous parenchyma, whereas plants cultured at $15^{\circ} \mathrm{C}$, the average value was 68 cells of this parenchyma (figures 7 and 9), correlating to the lower values of dry mass observed for plants of the latter treatment.
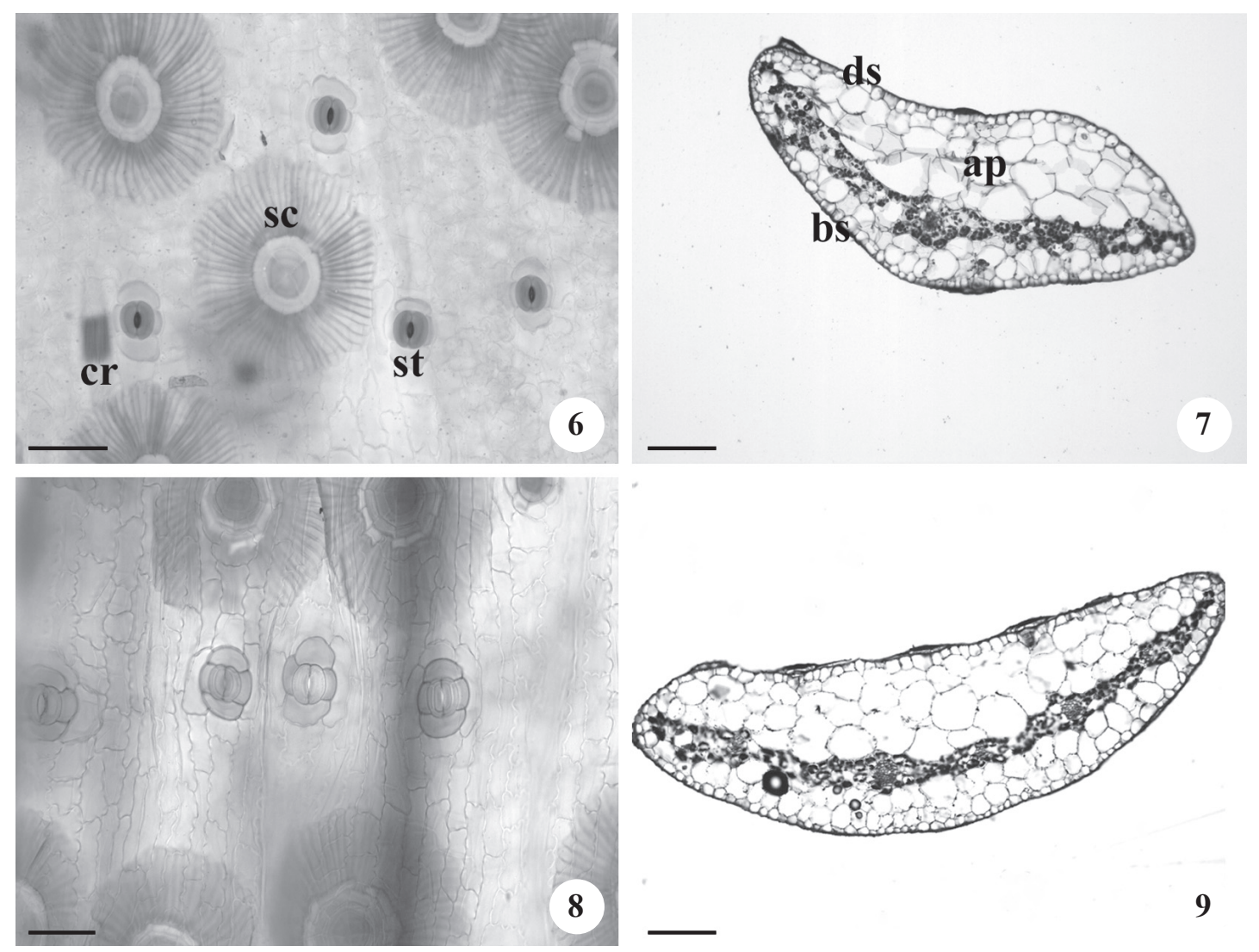

Figures 6-9. Photomicrographs of leaves of Vriesea inflata. 6,8. Frontal view, abaxial surface. 7-9. Cross-sections. 6-7. Plants cultured at $15{ }^{\circ} \mathrm{C}$. 8-9. Plants cultured at $28^{\circ} \mathrm{C}($ ap $=$ aquiferous parenchyma; bs = abaxial surface; $\mathrm{cr}=\mathrm{crystals}$; ds $=$ adaxial surface; $\mathrm{sc}=$ scales; $\mathrm{sp}=$ spongy parenchyma; $\mathrm{st}=$ stomata; uv = vascular unit). $\mathrm{Bar}=50 \mu \mathrm{m}(6,8) ; 100 \mu \mathrm{m}(7,9)$. 
In frontal view, anatomical analysis showed scamiform trichomes and tetracytic stomata (Evert 2006). In plants kept at $28^{\circ} \mathrm{C}$, stomata are more highly developed than in plants at $15{ }^{\circ} \mathrm{C}$. At both treatments no abnormality were observed in stomata structure. This result shows that the in vitro condition did not induce alterations in stomata morphology, contrary to that observed in Wrightia tomentosa (Roxb.) Roem. \& Schult. (Joshi et al. 2006). There was no difference in the amount of raphyde crystals in both treatments.

In spite of the smaller size of V.inflata plants kept at $15^{\circ} \mathrm{C}$, it was noted that the amount of leaves did not differ significantly, there being, therefore, no alteration in the general aspect of the plant (table 1). Pérez et al. (2001) noted that the drop in temperature from $25^{\circ} \mathrm{C}$ to $12{ }^{\circ} \mathrm{C}$ in the culture of fescue gave rise to inhibition of growth as expressed in leaf area. Clarkson et al. (1986), when working with Lolium perenne L., noted that in plants cultured at temperatures lower than $25^{\circ} \mathrm{C}$, less roots were formed when compared to those raised at $25^{\circ} \mathrm{C}$. This result was related to the fact that when temperature increased, the number of roots also increased, thus contributing to greater nutrient absorption at higher temperatures, thereby intensifying plant growth. Therefore, in relation to $V$. inflata plants studied in the present work, no difference was identified in relation to the number of roots in plants cultured in both treatments, however, length, dry and fresh masses increased at plants at $28^{\circ} \mathrm{C}$. Probably, these roots are important for fixation of bigger-sized shoot epiphyte bromeliad. These results are in accordance with the epiphytic habit of this species in nature, whose main roots' function is fixation (Medina 1974).

Ex vitro acclimatized plants had $100 \%$ survival after three months (table 2), and no noticeable morphological abnormalities in tissue cultured plants were observed even after three months of growth under greenhouse condictions. Results of this study provide a practical method to enhance commercial production and germplasm conservation of this plant. The use of seeds in this work allows the maintenance of the genetic diversity observed in the natural populations, as observed with the bromeliads Dyckia distachya Hassl. micropropagated (Pompelli \& Guerra 2005) and Tillandsia eizii L. B. Smith (Pickens et al. 2003), among others.

Interestingly, studies have shown that the transfer of plants cultured under in vitro conditions to growth in greenhouse, may be favored by the use of low temperatures, as commented by Campostrini \& Otoni (1996). According to Tadesse et al. (2000), at lower temperatures $\left(17^{\circ} \mathrm{C}\right)$ there was an increase in leaf area
Table 2. Rate of survival and growth of Vriesea inflata (Wawra) Wawra plants $(n=40)$ maintained in vitro at $15^{\circ} \mathrm{C}$ for two years and transferred to in vitro conditions at $28^{\circ} \mathrm{C}$ (Treatment I) and plants, from one year in vitro at $28^{\circ} \mathrm{C}$, acclimatizated for three months (Treatment II). Means with the same letter within the same line are not significantly different at the $5 \%$ level.

\begin{tabular}{lcc}
\hline & Treatment I & Treatment II \\
\hline \multirow{2}{*}{$\begin{array}{c}\text { Survival rate after } \\
\text { acclimatization }\end{array}$} & \multicolumn{2}{c}{$\%$} \\
\cline { 2 - 3 } & \multicolumn{2}{c}{$\bar{x} \pm s$} \\
\cline { 2 - 3 } & $4.70 \pm 0.46 \mathrm{~b}$ & $6.87 \pm 0.31 \mathrm{a}$ \\
Length of leaves (cm) & $100 \%$ \\
$\begin{array}{l}\text { Quantity of leaves } \\
\left(\mathrm{n}^{\circ}\right) / \text { plant }\end{array}$ & & \\
\hline
\end{tabular}

in Solanum tuberosum L., which could be related to the higher production of structural carbohydrates related to the process of climate adjustment. In this sense, the use of low temperatures could induce a type of resistance in the plant necessary at the phase of climate adjustment to ex vitro conditions. Verhoeven et al. (1999) observed that in Pinus ponderosa Douglas ex Lawson \& C. Lawson, the adjustment to a winter climate involved lower photosynthetic capacity and an increase in carotenoids rate in relation to that of chlorophylls and, on the other hand, Malva neglecta, presented higher photosynthesis rates in the winter than in the summer, and no alteration in the carotenoids/chlorophylls rate with the drop in temperature.

The present study was a source of information regarding in vitro growth of the bromeliad $V$. inflata at two temperatures. The establishment of in vitro culture starting from seeds harvested at natural environment (figures 1 and 2) contributes to maintaining the genetic variability of $V$. inflata. Results observed for plants kept at $15^{\circ} \mathrm{C}$ (figure $3 \mathrm{~A}$ ) and $28^{\circ} \mathrm{C}$ (figure 3B) showed reduced growth at $15{ }^{\circ} \mathrm{C}$. It is concluded that this species can be maintained in vitro at this temperature, with the aim of forming a collection of slow-growth plants for preservation, and they can be acclimatized (figures 4 and 5). This knowledge contributes to the future mounting of a germplasm bank containing plants of the same species from different populations.

Acknowledgements - We thank to Instituto de Botânica of Secretaria do Meio Ambiente do Estado de São Paulo/Brazil for permission to collect seeds of Vriesea inflata. 


\section{References}

AMOO, S.O., FINNIE, J.F. \& STADEN, J.V. 2009. effects of temperature, photoperiod and culture vessel size on adventitious shoot production of in vitro propagated Huernia hystrix. Plant Cell Tissue Organ Culture 99:233-238.

BEKHEET, S.A., TAHA, H.S. \& SAKER, M.M. 2002. In vitro long-term storage of date palm. Biologia Plantarum 45:121-124.

BELLINTANI, M.C., LIMA, C.C., BRITO, A.L., SANTANA, J.R.F. \& DORNELLES, A.L.C. 2007. Estabelecimento in vitro de Orthopytum mucugense e Neoregelia mucugensis, bromélias endêmicas da Chapada Diamantina, Bahia - Brasil. Revista Brasileira de Biociências 5:1101-1103.

BIGOT, J. \& BOUCAUD, J. 1996. Short-term responses of Brassica rapa plants to low root temperature: effects on nitrate uptake and its translocation to the shoot. Physiology Plantarum 96:646-654.

CAMPOSTRINI, E. \& OTONI, W.C. 1996. Aclimatização de plantas: abordagens recentes. http://www.cnph.embrapa. br/laborato/biocel/abctp25.htm (acesso em 23/12/2009).

CARTER, G.A. \& KNAPP, A.K. 2001. Leaf optical properties in higher plants: linking spectral characteristics to stress and chlorophyll concentration. American Journal of Botany 88:677-684.

CLARKSON, D.T., HOPPER, M.J. \& JONES, L.H.P. 1986. The effect of root temperature on the uptake of nitrogen and the relative size of the root system in Lolium perenne. I. Solutions containing both $\mathrm{NH}_{4}^{+}$and $\mathrm{NO}_{3}^{-}$. Plant, Cell and Environment 9:535-545.

DURAN, S. \& MONTEIRO, K. 2005. Jardim de luxo sustenta tráfico de plantas. www.biodiversityreporting. org (acesso em 23/12/2009).

EVERT, F.R. 2006. Esau's plant anatomy. John Wiley \& Sons, New Jersey.

FUNDAÇÃO BIODIVERSITAS. 2008. Lista da flora brasileira ameaçada de extinção. http://www. biodiversitas.org.br/florabr/lista_florabr.pdf (acesso em 23/12/2009).

GEORGIEVA, K. \& LICHTENTHALER, H.K. 2006. Photosynthetic response of different pea cultivars to low and high temperature treatments. Photosynthetica 44:569-578.

GONÇALVES, S. \& ROMANO, A. 2007. In vitro minimum growth for conservation of Drosophyllum lusitanicum. Biologia Plantarum 51:795-798.

HARTMANN, T.H., KESTER, D.E., DAVIES, F.T. \& GENEVE, R.L. 2002. Hartmann \& Kester's plant propagation: principles and practices. $7^{\text {th }}$ ed., Prentice Hall, New Jersey.

ISLAM, M.D.T., DEMBELE, D.P. \& KELLER, E.R.J. 2005. Influence of explant, temperature and different culture vessels on in vitro culture for germplasm maintenance of four mint accessions. Plant Cell, Tissue and Organ Culture 81:123-130.
JOHANSEN, D.A. 1940. Plant microtechnique. McGraw-Hill, New York.

JOSHI, P., JOSHI, N. \& PUROHIT, S.D. 2006. Stomatal characteristics during micropropagation of Wrightia tomentosa. Biologia Plantarum 50:275-278.

JOUVE, L., FRANCK, T., GASPAR, T., CATTIVELLI, L. \& HAUSMAN, J.F. 2000. Poplar acclimatization to cold during in vitro conservation at low non-freezing temperature: metabolic and proteic changes. Journal of Plant Physiology 157:117-123.

KLICH, M.G. 2000. Leaf variations in Elaeagnus angustifolia related to environmental heterogeneity. Environmental and Experimental Botany 44:171-183.

LICHTENTHALER, H.K. 1987. Chlorophylls and carotenoids: pigments of photosynthetic biomembranes. In Methods in enzymology (L. Packer \& R. Douce, eds.). Academic Press, London, v.148, p.350-382.

LUTHER, H.E. 2006. An alphabetical list of bromeliad binomials. $10^{\text {th }}$ ed., The Bromeliad Society International, Sarasota.

MALIK, S., KUMAR, R., VATS, S.K., BRUSHAN, S., SHARMA, M. \& AHUJA, P.S. 2009. Regeneration in Rheum emodi Wall.: a step towards conservation of an endangered medicinal plant species. Engineering in Life Sciences 9:130-134.

MEDINA, E. 1974. Dark $\mathrm{CO}_{2}$ fixation, habitat preference and evolution within the Bromeliaceae. Evolution 28: 677-686.

MERCIER, H. \& NIEVOLA, C.C. 2003. Obtenção de bromélias in vitro como estratégia de preservação. Vidália 1:57-62.

MURASHIGE, T. \& SKOOG, F. 1962. A revised medium for rapid growth and bioassays with tobacco tissue cultures. Physiologia Plantarum 15:473-497.

NIEVOLA, C.C., KRAUS, J.E., FRESCHI, L., SOUZA, B.M. \& MERCIER, H. 2005. Temperature determines the occurrence of CAM or $\mathrm{C}_{3}$ photosynthesis in pineapple plantlets grown in vitro. In Vitro Cellular \& Development Biology Plant 41:832-837.

NUNES, J.V.C. 2002. Bromélias. In Sustentável Mata Atlântica (L.L. Simões \& C.F. Lino, eds.). Editora Senac, São Paulo, p.119-132.

PÉREZ, P., MORCUENDE, R., MOLINO, I.M., PUENTE, L.S. \& MARTINEZ-CARRASCO, R. 2001. Contrasting responses of photosynthesis and carbon metabolism to low temperatures in tall fescue and clovers. Physiology Plantarum 112:478-486.

PICKENS, K.A., AFFOLTER J.M. \& WETZSTEIN H.Y. 2003. Enhanced seed germination and seedling growth of Tillandsia eizii in vitro. Hortscience 38:101-104.

PIERIK, R.L.M. 1987. In vitro culture of higher plants. Martinus Nijhoff Pyblishers, Dordrecht.

POMPELLI, M.F. \& GUERRA, M.P. 2005. Micropropagation enables the mass propagation and conservation of Dyckia distachya Hassler. Crop Breeding and Applied Biotechnology 5:117-124. 
RECH-FILHO, A., DAL VESCO, L.L. \& GUERRA, M.P. 2009. Adventitious shoots from nodule cluster cultures of Vriesea reitzii: an endemic and endangered bromeliad from atlantic forest. Ciência Rural 39:909-912.

ROCHA, C.F.D., COGLIATTI-CARVALHO, L., NUNES-FREITAS, A.F., ROCHA-PESSÔA, T.C., DIAS, A.S., ARIANI, C.V. \& MORGADO, L.N. 2004. Conservando uma larga porção da diversidade biológica através da conservação de Bromeliaceae. Vidália 2: 52-68.

SARASAN, V., CRIPPS, R., RAMSAY, M.M., ATHERTON, M.M., PRENDERGAST, G. \& ROWNTREE, J.K. 2006. Conservation in vitro of threatened plants: progress in the past decade. In Vitro Cellular \& Development Biology Plant 42:206-214.

SILVA, A.L.L., DORNELlES, E.B., BISOGNIN, D.A., FRANCO, E.T.H. \& HORBACH, M.A. 2007. Micropropagation of Dyckia agudensis Irgang \& Sobral - an extinction threatened bromeliad. Iheringia 62:39-43.
SILVEIRA, D.G., SOUZA, F.V.D., PELACANI, C.R., SOUZA, A.S., LEDO, C.A. \& SANTANA, J.R.F. 2009. Micropropagation and in vitro conservation of Neoglaziovia variegata (Arr. Cam.) Mex, a fiber producing bromeliad from Brazil. Brazilian Archives of Biology and Technology 52:923-932.

STRITTMATER, C.G.D. 1973. Nueva tecnica de diafanizacion. Boletín de la Sociedad Argentina de Botánica 15:126-129.

TADESSE, M., LOMMEN, W.J.M. \& STRUIK, P.C. 2000. Effects of in vitro treatments on leaf area growth of potato transplants during acclimatization. Plant Cell, Tissue and Organ Culture 61:59-67.

VERHOEVEN, A.S., ADAMS III, W.W. \& DEMMIGADAMS, B. 1999. The xanthophyll cycle and acclimatization of Pinus ponderosa and Malva neglecta to winter stress. Oecologia 18:277-287.

VON WIREN, N., GAZZARRINI, S. \& FROMMER, W.B. 1997. Regulation of mineral nitrogen uptake in plants. Plant and Soil 196:191-199. 